\title{
Congenital Hyperinsulinism in China: A Review of Chinese Literature Over the Past 15 Years
}

\author{
Wei-Yan Wang ${ }^{1}$, Yi Sun ${ }^{1}$, Wen-Ting Zhao ${ }^{1}$, Tai $\mathbf{W u}^{1}$, Liang Wang ${ }^{2}$, Tian-Ming Yuan ${ }^{1}$, Hui-Min $\mathrm{Yu}^{1}$ \\ ${ }^{1}$ Zhejiang University School of Medicine, Children's Hospital, Clinic of Neonates, Hangzhou, China \\ ${ }^{2}$ Zhejiang Cancer Hospital, Clinic of Chest Surgery, Hangzhou, China
}

\section{What is already known on this topic?}

Several studies have already summarized the clinical and genetic characteristics of congenital hyperinsulinism (CHI) in Beijing and Shanghai cities.

\section{What this study adds?}

Studies throughout China are still scarce. Our article reviewed the clinical presentation, therapeutic outcomes, and genetic mutations of $\mathrm{CHI}$ in the Chinese population over the past 15 years and also compared the $\mathrm{CHI}$ in China with that in other countries.

\begin{abstract}
Objective: Congenital hyperinsulinism (CHI) is a rare but severe cause of hypoglycemia. The present study investigates the clinical presentation, therapeutic outcomes and genetic mutations of $\mathrm{CHI}$ in Chinese individuals over the past 15 years.

Methods: The authors retrospectively reviewed one case in their department and 206 cases reported from January 2002 to October 2016 in China. PubMed, Ovid Medline, Springer and Wanfang Database, CBMD database, and CKNI database were the sources used to collect the data.

Results: In total, 207 cases were recruited. Of these, the ages of $100(48.3 \%)$ were within the $4^{\text {th }}$ week after birth. Seventy-seven cases $(37.2 \%)$ were born large for gestational age (LGA). Seizures occurred in 140 cases (67.6\%). Among 140 cases (67.6\%) who were administered diazoxide treatment, $90(64.3 \%)$ were responsive. Seven cases $(3.4 \%)$ received octreotide treatment and 19 cases $(9.2 \%)$ underwent surgery. $63 / 129$ cases (48.8\%) were detected to have gene mutations, including ABCC8 (69.8\%), KCNJ11 (12.7\%), GLUD1, GCK, $H A D H$, and HNF4A. Among the diazoxide-unresponsive cases, gene mutations were detected in 20/36 (55.6\%) cases with $A B C C 8$ and in $2(5.6 \%)$ cases with KCNJ11. Among the diazoxide-responsive cases, gene mutations were detected in 8 patients with ABCC8, 4 with KCNJ11, 5 with GLUD1, and 1 with GCK.

Conclusion: The present study indicates that most CHI cases occurred in neonates and that $1 / 3$ of the cases were born LGA. $A B C C 8$ and $K C N J 11$ are the most common gene mutations. More than half of the diazoxide-unresponsive CHI detected mutations are in $A B C C 8$ and KCNJ11 genes. The GLUD1 gene mutations cause diazoxide-responsive CHI. Identifying the gene mutations can assist in the diagnosis and treatment of $\mathrm{CHI}$.
\end{abstract}

Keywords: Congenital hyperinsulinism, neonate, clinical presentation, gene mutation

\section{Introduction}

Congenital hyperinsulinism (CHI) is due to inappropriate insulin secretion in the course of hypoglycemia (1). It is the most common cause of severe and persistent hypoglycemia in newborns and infants. The incidence of $\mathrm{CHI}$ is reported to be $1 / 50.000$ live births in a random mating population; however, it can be as high as 1/2500 in communities with high rates of consanguinity $(2,3)$. The clinical presentation of $\mathrm{CHI}$ is heterogeneous and varies by age. The severity of hypoglycemia varies from asymptomatic hypoglycemia revealed by a routine blood glucose test to a state of serious hypoglycemic coma or seizures. Major clinical manifestations of $\mathrm{CHI}$ reported by other studies include 
macrosomia, large for gestational age (LGA), seizures, cyanosis, food refusal, lethargy, hypoglycemia, and atypical facial appearance including high forehead with a thin upper lip. Although the clinical symptoms of $\mathrm{CHI}$ can reflect the severity to some extent, they serve little to aid the clinicians in the selection of regimen, which is usually correlated with the histopathology of $\mathrm{CHI}$.

Histologically, there are focal and diffuse forms of conditions leading to $\mathrm{CHI}$ (4). Focal lesions, which account for approximately $40-50 \%$ of all cases, require a partial pancreatectomy. This form typically occurs during infancy rather than in older children. On the other hand, a similar number of cases present with a dysfunctional ATP sensitive potassium $\left(\mathrm{K}_{\text {АтР }}\right)$ channel involving the entire pancreas which leads to severe hypoglycemia, requiring a near total pancreatectomy (5). The clinical presentations and prognosis of patients with $\mathrm{CHI}$ depend primarily on the histopathology of the pancreas. Most patients with focal forms recover well after surgery, while some diffuse forms show persistent hypoglycemia even after surgery. Thus, it is necessary to differentiate the two forms. However, the clinical symptoms of $\mathrm{CHI}$ are non-specific, and thus, additional tools are essential in distinguishing the focal lesions from diffuse forms.

In recent years, the understanding of the genetic mechanisms of $\mathrm{CHI}$ has made progress. Mutations in 11 genes, including $A B C C 8, K C N J 11, G L U D 1, G C K, H A D H$, UCP2, SLC16A1 (MCT1), HNF4A, HNF1A (6), HK1 (7), and PGM1 (8) are known to cause CHI. Among them, the most common and most severe forms of $\mathrm{CHI}$ are speculated to be associated with the mutations of the $\mathrm{K}_{\text {ATP }}$ channel genes ( $A B C C 8$ and KCNJ11), encoding the sulfonylurea receptor 1 (SUR1) and Kir6.2 subunits, respectively. Fournet and Junien (9) demonstrated that in about $50 \%$ of $\mathrm{CHI}$ cases, recessive mutations in the $\mathrm{K}_{\text {ATP }}$ channel genes cause a diffuse pathology that necessitates a near total pancreatectomy, whereas the loss of heterozygosity together with the inheritance of a paternal mutation causes focal lesion that needs a partial pancreatectomy. Thus, the gene mutation type could assist in diagnosing, differentiating, and identifying the histological type of $\mathrm{CHI}$ and in treating the disease.

Though the disease is uncommon, the hypoglycemia caused by $\mathrm{CHI}$ can sometimes be extremely severe, frequently leading to severe neurological damage or even death in infancy. Therefore, it is important to diagnose and treat these infants with $\mathrm{CHI}$ at the earliest to alleviate the degree of brain damage. Several studies $(10,11,12,13)$ have already summarized the clinical and genetic characteristics of $\mathrm{CHI}$ in Beijing and Shanghai; however, studies throughout China are yet lacking. In this article, we aimed to review the present knowledge on the clinical presentation, therapeutic outcomes, and genetic mutations of $\mathrm{CHI}$ in the Chinese population and to compare this knowledge with that in other countries.

\section{Methods}

The search for case reports and case series on confirmed cases of CHI between January 2002 and October 2016 from PubMed, Ovid Medline, Springer and Wanfang Database, CBMD database, and CKNI database retrieved 19 case reports and case series published in core Chinese journals and 4 in journals publishing in English. Three series that summed up the earlier case reports, 4 case reports in Chinese, and 1 case in English were excluded to avoid overlapping. Thus, 12 articles in Chinese and 3 in English, encompassing 207 patients (including 1 case from our department) were included in the survey. The clinical presentation, therapeutic outcomes and genetic mutations of all these $207 \mathrm{CHI}$ patients were analyzed.

A low level of fasting hypoglycemia $(<2.8 \mathrm{mmol} / \mathrm{L})$ requiring a high rate of IV glucose infusion ( $>8 \mathrm{mg} / \mathrm{kg} /$ min) to maintain a normal blood glucose level, presence of a detectable insulin level during hypoglycemia, a glycemic response to glucagon injection, undetectable fatty acid and ketone levels and a normal or increased serum ammonia level constituted the diagnostic criteria for $\mathrm{CHI}(14)$.

\section{Results}

A total of 207 cases, 1 case from our own department together with the 206 cases of $\mathrm{CHI}$ reported previously from China $(11,12,13,15,16,17,18,19,20,21,22,23,24,25,26)$ were available for analysis. Among them, 154 cases were from Beijing city, 32 from Shanghai city, 14 from Guangdong province, 4 from Zhejiang province, and 1 case each from Hunan, Sichuan, and Shandong provinces.

As shown in Table 1, of the 207 cases, 157 (75.8\%) were less than 1-year-old. Among these, 100 cases $(48.3 \%)$ were only 4 weeks old. The patients were males in 114 cases (55\%), females in 93 cases $(45 \%)$, and the male-to-female ratio was $1.23: 1$. The birth weight of the series ranged from 1.9 to $5.8 \mathrm{~kg}$. Seizures occurred in 140 cases $(67.6 \%)$, whereas other symptoms such as cyanosis, food refusal, and lethargy were reported in 67 cases $(32.3 \%)$. Seventy-seven out of $207(37.2 \%)$ cases were born LGA.

Blood tests showed that the blood glucose level of all cases was $<2.8 \mathrm{mmol} / \mathrm{L}$ and the lowest glucose level reported was $0.3 \mathrm{mmol} / \mathrm{L}$. High levels of insulin $(2.4-220 \mu \mathrm{lU} / \mathrm{mL})$ were observed in all patients. High levels of ammonia (17- 
$128 \mathrm{mmol} / \mathrm{L}$ ) were detected among a subgroup of cases. Only 1 case was found with focal lesions in the head of pancreas using F-dihydroxyphenylalanine positron emission tomography/computed tomography (F-DOPA PET/CT).

In this series, of the 140 cases $(67.6 \%)$ who were treated with oral diazoxide, 90 cases $(64.3 \%)$ reached a normal blood glucose level before discharge from the hospital. Only 7 cases $(3.4 \%)$ received octreotide treatment, and 4 of these 7 cases $(57.1 \%)$ reached a normal blood glucose level. Nineteen cases $(9.2 \%)$ underwent surgery, and in 14 of these 19 cases $(73.7 \%)$, blood glucose reached a normal level.

One hundred-twenty nine cases underwent gene mutation test, and 63 of these cases $(48.8 \%)$ showed mutations in ABCC8, KCNJ11, GLUD1, GCK, HADH, and HNF4A genes. Two of these cases were found to be homozygous for ABCC 8 mutation ( 1 case unresponsive to diazoxide, and the other with unknown diazoxide response). Three cases were found

\section{Table 1. Clinical characteristics of congenital hyperinsulinism in Chinese patients}

\begin{tabular}{ll}
\hline Characteristic & \\
\hline Sex (Male:Female) & $114: 93(1.23: 1)$ \\
Age of onset & $\mathrm{n}=100(48.3 \%)$ \\
Neonate (0-4 weeks) & $\mathrm{n}=57(27.5 \%)$ \\
Infancy (1-12 months) & $\mathrm{n}=50(24.2 \%)$ \\
Childhood (>12 months) & $1.9-5.8 \mathrm{~kg}$ \\
Birth weight (range) & $\mathrm{n}=77(37.2 \%)$ \\
Macrosomia & \\
Complaints & $\mathrm{n}=140(67.6 \%)$ \\
Seizures & $\mathrm{n}=67(32.4 \%)$ \\
Other (cyanosis, food refusal, lethargy) & $0.3-2.8 \mathrm{mmol} / \mathrm{L}$ \\
Blood glucose level (range) & $17-128 \mathrm{mmol} / \mathrm{L}$ \\
Blood ammonia level (range) & $(2.4-220) \mu \mathrm{lU} / \mathrm{mL}$ \\
\hline
\end{tabular}

\begin{tabular}{|c|c|c|c|c|c|c|c|}
\hline \multirow[t]{2}{*}{ Case } & \multirow[t]{2}{*}{ Sex } & \multirow[t]{2}{*}{ Birth weight (kg) } & \multirow{2}{*}{$\begin{array}{l}\text { Disease } \\
\text { onset }\end{array}$} & \multirow[t]{2}{*}{ Gene } & \multirow[t]{2}{*}{ Mutation } & \multicolumn{2}{|c|}{ Inherited from } \\
\hline & & & & & & Father & Mother \\
\hline 3 & Male & 4.4 & Neonate & $A B C C 8$ & c. $331 \mathrm{G}>$ A;p.G111R* & p.G111R & Negative \\
\hline 5 & Male & 3.2 & Infancy & $A B C C 8$ & c. 1473 T > G;p.Y491 * & Negative & Negative \\
\hline 12 & Male & 5.12 & Neonate & $A B C C 8$ & c. 4478G > A;p.R1493Q** & p.R1493Q & Negative \\
\hline 13 & Female & 3.15 & Infancy & $A B C C 8$ & c. $4374 G$ > C;p.Q1458H & NA & NA \\
\hline 20 & Female & 4.2 & Neonate & $A B C C 8$ & c.3650G > A;p.R1217K* & Negative & p.R1217K \\
\hline 21 & Female & 3.6 & Infancy & $A B C C 8$ & c. 4478G > A;p.R1493Q** & R1493Q & Negative \\
\hline 38 & Not mentioned & Not mentioned & Infancy & $A B C C 8$ & c.3832G > A;p.G1255S & NA & NA \\
\hline 41 & Female & 4.8 & Neonate & $A B C C 8$ & c.4613G > A;p.R1538Q & NA & NA \\
\hline 42 & Female & 3.2 & Infancy & KCNJ11 & c.881 C > T; p.T294M & p.T294M & Negative \\
\hline 43 & Female & 3.2 & Neonate & KCNJ11 & c.407G > T; p.R136L & NA & NA \\
\hline 45 & Male & 4.415 & Neonate & KCNJ11 & c.146T > A;p.I49N & NA & NA \\
\hline 48 & Not mentioned & Not mentioned & Neonate & KCNJ11 & c.91 G > A;p.R31W & NA & NA \\
\hline 50 & Female & 3.35 & Infancy & GLUD1 & c. $820 \mathrm{C}>\mathrm{T} ; \mathrm{R} 221 \mathrm{C}$ & NA & NA \\
\hline 52 & Male & 3.2 & Infancy & GLUD1 & c. $1516 \mathrm{G}>\mathrm{A} ; \mathrm{V} 453 \mathrm{M}$ & NA & NA \\
\hline 53 & Male & 3.6 & Infancy & GLUD1 & c. $978 \mathrm{G}>\mathrm{A} ; \mathrm{R} 269 \mathrm{H}^{*}$ & Negative & Negative \\
\hline 54 & Male & 3.5 & Infancy & GLUD1 & c. $1506 \mathrm{C}>\mathrm{T} ; \mathrm{S} 445 \mathrm{~L}$ & Negative & Negative \\
\hline 55 & Male & 3.2 & Infancy & GLUD1 & c. $978 \mathrm{G}>\mathrm{A} ; \mathrm{R} 269 \mathrm{H}$ & $\mathrm{R} 269 \mathrm{H}$ & Negative \\
\hline 57 & Male & 5 & $>1$ year & GCK & c.295C > T;p.W99R & Negative & Negative \\
\hline 59 & Female & 3.35 & Infancy & $H N F 4 A$ & c. ${ }^{*} 7 \mathrm{G}>\mathrm{A}$; Unkown & NA & NA \\
\hline 60 & Female & 4 & Neonate & $H N F 4 A$ & c.416C > T;p.T139I & NA & NA \\
\hline \multicolumn{8}{|c|}{ * Means the gene mutation appears twice in the study } \\
\hline \multicolumn{8}{|c|}{$\uparrow$ Means the gene mutation appears three times in the study } \\
\hline \multicolumn{8}{|c|}{ Negative means negative result of gene mutation test } \\
\hline \multicolumn{8}{|c|}{ NA means gene mutation test is not available } \\
\hline \multicolumn{8}{|c|}{ “Means the case was from the authors' department of neonate } \\
\hline \multicolumn{8}{|c|}{ * Means missense mutation altering protein function } \\
\hline
\end{tabular}


to be compound heterozygous for ABCC 8 mutation (2 cases diazoxide-responsive, 1 case with unknown diazoxide response), 15 cases were found to have heterozygous mutation in ABCC8 gene (9 cases diazoxide-unresponsive, 4 cases diazoxide-responsive, and 2 cases with unknown diazoxide responsiveness). Two cases were found to possess heterozygous mutation in KCNJ11 gene (1 case diazoxideunresponsive, the other one diazoxide-responsive); 1 case was found to have heterozygous mutation in GLUD1 gene (diazoxide-responsive), 8 cases had de novo mutations (5 ABCC8, 2 GLUD 1, 1 GCK), and 32 cases were not analyzed for the parents' gene mutation test (Figure 1).

In this series, 63 cases were detected to possess 60 gene mutations, including 39 mutations in $A B C C 8$ gene, 8 in KCNJ11, 6 in GLUD1, 2 in GCK, 3 in $H A D H$, and 2 mutations in $H N F 4 A$ gene. Mutations in $A B C C 8$ gene were detected in 8 cases; one mutation in KCNJ11 gene and one in GLUD1 gene appeared twice.

We recruited 90 cases who went through gene mutation test and received diazoxide treatment. Among them, 54 cases were responsive to diazoxide and 20 were detected to have positive gene mutations. These mutations were as follows: in ABCC8 gene-8 cases, in KCNJ11-4, in GLUD1-5, in HNF4A-2, and in GCK gene- 1 case (Table 2). The other 36 cases were unresponsive to diazoxide treatment, and 22 cases were detected to have positive gene mutation. These gene mutations were in $A B C C 8$ gene in 20/36 cases (55.6\%) and in KCNJ11gene in 2 cases (5.6\%) (Table 3).

\section{Discussion}

Most of the patients in the series were the offspring of families who resided in the eastern part of China. The vast majority of $\mathrm{CHI}$ cases were from Beijing and Shanghai cities and Guangdong and Zhejiang provinces, though a small number of cases were also reported from other regions such as Hunan, Sichuan, and Shandong provinces. To our knowledge, this is the first report involving the distribution of $\mathrm{CHI}$. We speculated that this geographic disequilibrium was partially due to the disequilibrium of the economy and to missed cases due to ignorance and misdiagnosis of this disease in different areas of China related to social, economic factors. Possibly, the medical personnel in those areas did not realize the significance of identifying the cause of persistent hypoglycemia and did not attempt to investigate the gene mutation status in these patients.

In our study, $48.3 \%$ of cases were found to present clinical manifestation of $\mathrm{CHI}$ within 4 weeks after birth. This finding was similar to the results of a Taiwanese study with $46 \%$ of cases with neonatal onset (27). Our study also demonstrates that macrosomia can often be observed among the patients, and LGA accounts for $37.2 \%$. We speculate that the underlying reason for macrosomia should be ascribed to be the severe prenatal hyperinsulinism. A study comprising 114 patients (28) revealed that $27 \%$ of patients with neonatalonset $\mathrm{CHI}$ had a birth-weight SDS of $>2$. Shen et al (22) reported 15 neonatal cases of $\mathrm{CHI}$, of which 10 cases were LGA and blood glucose level returned to normal in only 3 patients in this series. Thus, we propose that an early-onset

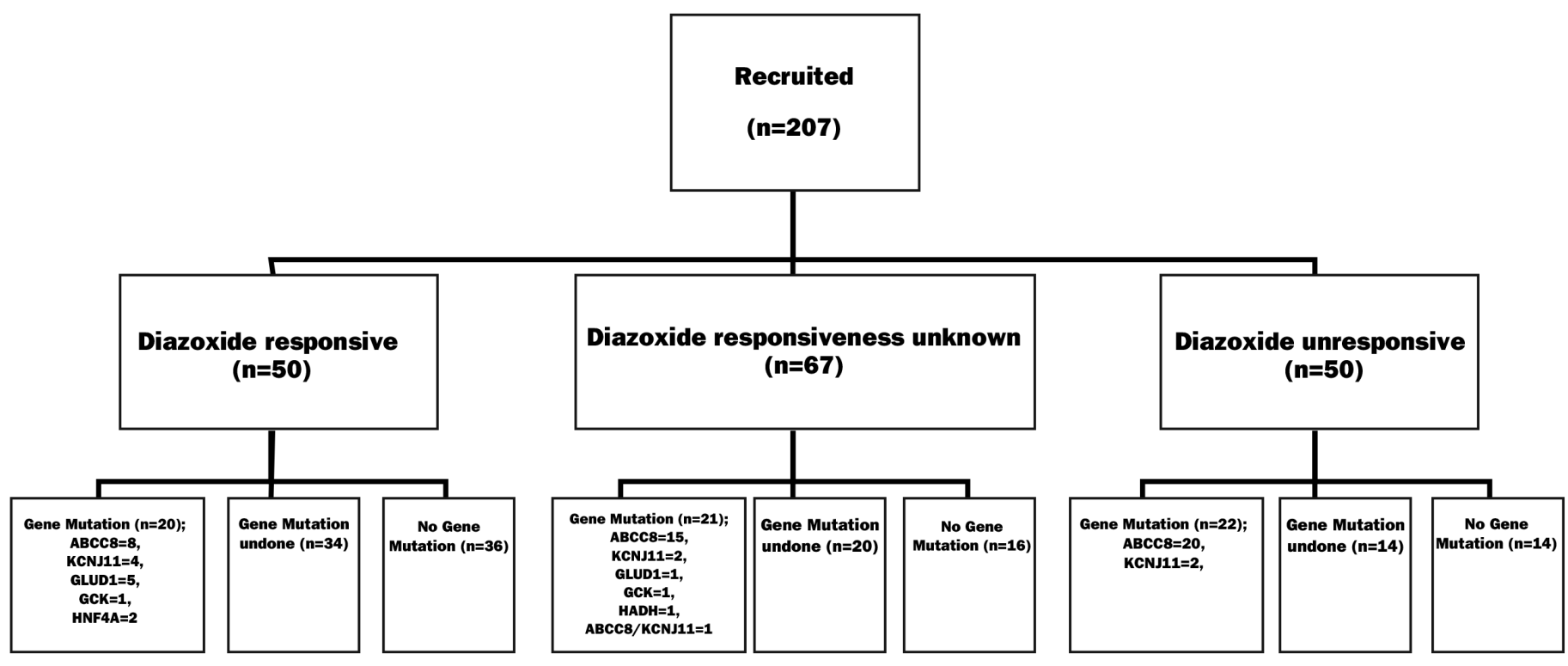

Figure 1. Gene mutation distribution of 63 cases detected in 129 cases 


\begin{tabular}{|c|c|c|c|c|c|c|c|}
\hline \multirow[t]{2}{*}{ Case } & \multirow[t]{2}{*}{ Sex } & \multirow{2}{*}{$\begin{array}{l}\text { Birth weight } \\
\text { (kg) }\end{array}$} & \multirow{2}{*}{$\begin{array}{l}\text { Disease } \\
\text { onset }\end{array}$} & \multirow[t]{2}{*}{ Gene } & \multirow[t]{2}{*}{ Mutation } & \multicolumn{2}{|l|}{ Inherited from } \\
\hline & & & & & & Father & Mother \\
\hline 6 & Male & 4.4 & Neonate & $A B C C 8$ & c.3000C > A;p.C1000** & p.C1000* & Negative \\
\hline 7 & Male & 4.6 & Neonate & $A B C C 8$ & $\begin{array}{l}\text { c. } 4661 \mathrm{G}>\text { A;p.G1554D; } \\
\text { c.1501G > A;p.E501K }\end{array}$ & p.G1554D & p.E501K \\
\hline 8 & Male & 3.7 & Neonate & $A B C C 8$ & c.3888G > A;p.W1296* & p.W1296* & Negative \\
\hline 9 & Male & 3.4 & Infancy & $A B C C 8$ & c.86A > G;p.D29G & NA & NA \\
\hline 10 & Male & 2.52 & Neonate & $A B C C 8$ & c.331G > A;p.G111 R* & NA & NA \\
\hline 11 & Female & - & Infancy & $A B C C 8$ & $\begin{array}{l}\text { c. } 863 G>A ; p . W 288^{* *} ; \text { c. } 2506 C> \\
\text { T; p.R836** }\end{array}$ & p.W288* & p.R836* \\
\hline 14 & Female & 3.6 & Neonate & $A B C C 8$ & c. 1792 C > T;p.R598** & p.R598* & Negative \\
\hline 15 & Female & 3.6 & Neonate & $A B C C 8$ & c.276_277insCATC;p.Ile93Hisfs*3 & p.Ile93Hisfs*3 & Negative \\
\hline 16 & Female & 4.6 & Neonate & $A B C C 8$ & c.4478G > A;p.R1493Q* & p.R1493Q & Negative \\
\hline 17 & Female & 4.7 & Neonate & $A B C C 8$ & c.1887delc; P629PfsX17 & P629PfsX17 & Negative \\
\hline 18 & Male & 4.4 & Neonate & $A B C C 8$ & c. $863 G>$ A;p.W288** & p.W288* & Negative \\
\hline 19 & Female & 4.2 & Infancy & $A B C C 8$ & $\begin{array}{l}\text { C. } 1919 \text { C > T;A640V;C.3586C > } \\
\text { T;p.Q1196* }\end{array}$ & p.Q1196* & Negative \\
\hline 23 & Male & 3.4 & Infancy & $A B C C 8$ & c.3000C > A;p.C1000** & p.C1000* & Negative \\
\hline 24 & Female & 5.28 & Neonate & $A B C C 8$ & c. $4513 G>C ; D 1505 H$ & Negative & Negative \\
\hline 25 & Female & 4.5 & Neonate & $A B C C 8$ & c. 1421 A > G; Q474R & Negative & Negative \\
\hline 26 & Female & 4.05 & Neonate & $A B C C 8$ & c. 1792 C > T;p.R598** & Negative & Negative \\
\hline 37 & Male & 3.9 & Neonate & $A B C C 8$ & c.2990G > A;p.W997* & NA & NA \\
\hline 39 & Not mentioned & Not mentioned & Infancy & $A B C C 8$ & c.1861 C > T;p.R598X & NA & NA \\
\hline $40^{\prime \prime}$ & Male & 5.8 & Neonate & $A B C C 8$ & c.2797C > T;p.R933* & p.R933* & p.R933* \\
\hline 44 & Male & 4.2 & Infancy & KCNJ11 & c.703C > G; Q235E & Q235E & Negative \\
\hline 49 & Not mentioned & Not mentioned & Neonate & KCNJ11 & c.101 C > T;p.R34H & NA & NA \\
\hline 61 & Male & 4.25 & Neonate & $\begin{array}{l}A B C C 8 / \\
H A D H\end{array}$ & $\begin{array}{l}\text { c.2506C > T;p. } \\
\text { R836**;c.2797C > T;p. } \\
\text { R933**/c.719G > T;p.T240M }\end{array}$ & NA & NA \\
\hline
\end{tabular}

* Means the gene mutation appears twice in the study

$\downarrow$ Means the gene mutation appears three times in the study

Negative means negative result of gene mutation test

NA means gene mutation test is not available

“Means the case was from the authors' department of neonate

${ }^{*}$ Means missense mutation altering protein function

age of $\mathrm{CHI}$ together with a high birth weight are indicators of severity of this condition.

In addition, our findings demonstrate that seizures frequently occurred in CHI, as reported by Ferry et al (29) and that cyanosis, food refusal, lethargy, and hypoglycemia are also features of CHI. The clinical presentation is nonspecific, and the conventional ultrasound scan, computed tomography, and magnetic resonance imaging could not detect any lesion.

The findings of this study show that diazoxide is the firstline treatment in this condition. The positive response rate $(64.3 \%)$ to diazoxide in our sample is in accordance with that of $66 \%$ in 175 cases of $\mathrm{CHI}$ reported by de Lonlay et al (30). We recruited only 7 cases receiving octreotide treatment, 4 of these cases were responsive. Although octreotide treatment could be used in diazoxide-unresponsive cases, it could cause cholestasis and hepatitis $(31,32)$. Elevated levels of liver enzymes and gallbladder pathology were detected in the patients treated. Octreotide treatment may also impose an enormous economic burden on the family, thereby, limiting its clinical usage.

Surgery is the last option for drug-resistant $\mathrm{CHI}$ patients. In our review, 19 such cases underwent the operation and 14 of these cases were restored to normal glucose level after 
surgery. However, since F-DOPA PET/CT is not available in Mainland China, most patients are obliged to undergo a subtotal pancreatectomy and endure the risk of becoming a diabetic as a side-effect.

Nevertheless, now that gene mutation test is available, several researchers are focusing on the relationship between diazoxide treatment and gene mutation type. Previously, the reasons for the differences in responsiveness to diazoxide treatment were unknown and were ascribed by some researchers to different histological patterns of $\mathrm{CHI}$ (33). Snider et al (6) reported that $91 \%$ of diazoxide-unresponsive cases were correlated with recessive KATP channel gene mutations, while $41 \%$ of diazoxide-responsive cases were correlated with dominant $\mathrm{K}_{\text {ATP }}$ mutations.

In our study, 129 cases underwent gene mutation test and $48.8 \%$ of these cases were detected to have a gene mutation, which is a much lower frequency than that reported by Park et al (33). These authors reported a frequency of $82 \%$ as mutation findings in a Korean population. However, our results are similar to those of other researchers who reported a frequency of $45.3 \%$ mutations in $\mathrm{CHI}$ patients (34). These differences in frequency may be partially due to differences in ethnicity-related genetics. Moreover, Park et al (33) recruited only 17 patients, and thus, a large-scale cohort is essential to illustrate the frequency in a population. Among the 63 cases of gene mutation detected in our series, the $\mathrm{K}_{\text {ATP }}$ channel gene mutations ( $A B C C 8$ or KCNJ11) account for $82.5 \%$ of the gene mutations; this result is similar to the $84.2 \%$ frequency reported by Yorifuji et al (34) and $80.1 \%$ by Kapoor et al (35).

We detected 60 gene mutations out of 63 cases in the Chinese population, with $8 A B C C 8,1$ KCNJ11, and 1 GLUD1 gene mutations appearing twice, and $2 A B C C 8$ gene mutations appearing three times. This is the first report to sum up the occurrence rate of gene mutations in a population and we hope these findings will facilitate the clinicians' work in $\mathrm{CHI}$ cases.

Our results indicate that all GLUD1 gene mutations contribute to diazoxide responsiveness. This finding is in accordance with the study by Snider et al (6). Some cases with a heterozygous $A B C C 8 / K C N J 11$ mutation are also diazoxide-responsive, which is similar to the result of Kapoor et al (35). GCK mutation may also be attributed to diazoxideresponsive $\mathrm{CHI}$; in most cases it is medically responsive, although in some cases, surgery may be required (36). Two HNF4A gene mutation cases were diazoxide-responsive in our study; Kapoor et al (37) also elucidated that CHI patients with $H N F 4 A$ can exhibit mild, transient to severe, persistent hypoglycemia and are diazoxide-responsive.
We also demonstrated that the cases with compound heterozygous recessively acting $A B C C 8 / K C N J 11$ mutations, or homozygous $A B C C 8 / K C N J 11$ recessively acting mutation, or some cases with a heterozygous $A B C C 8 / K C N J 11$ mutation may show diazoxide-unresponsiveness, which is in accordance with the results of Kapoor et al (35).

In our study, one $A B C C 8$ gene mutation (c.331G > A; p.G111R) occurred twice, but one case was responsive to diazoxide treatment, while the other was unresponsive. The reason for this difference in response is unknown, but we see that the responsive case had a paternally inherited heterozygous mutation, while a gene mutation test was not performed in the parents of the unresponsive case. It can be speculated that the unresponsive case may have had a paternally inherited mutation and loss of heterozygosity that caused focal CHI.

Nowadays, the gene mutation test can be conducted easily with rapid results in some developed countries. However, in China, the cost of gene mutation test is high and it takes a long time to obtain the results. One of the aims of this study was to facilitate the diagnosis and treatment of $\mathrm{CHI}$ by the clinician in China, where F-DOPA PET/CT is not available. Some gene mutations appearing two or three times may indicate their frequent occurrence in the Chinese population.

In conclusion, our study suggests that nearly half of $\mathrm{CHI}$ cases occur in neonates, and the most common symptom is seizures. The first-line treatment of $\mathrm{CHI}$ is diazoxide treatment, octreotide is not used often, and surgery is the option due to drug unresponsiveness. F-DOPA PET/CT is not available in Mainland China. In Chinese patients, $A B C C 8$ and KCNJ11 are the most common gene mutations, and GLUD1 ranks second. Half of the gene mutations of diazoxideunresponsive $\mathrm{CHI}$ are KATP ( $A B C C 8$ and KCNJ11) mutations, homozygous or compound heterozygous mutations, and some are a heterozygous $A B C C 8$ mutation. GLUD1 always caused diazoxide-responsive $\mathrm{CHI}$.

$\mathrm{CHI}$ is a complex disorder with non-specific presentations. Our study suggests that gene mutation test is now performed more frequently in China, although not as often as in other developed countries. Obtaining rapid results in genetic testing is uniquely valuable for $\mathrm{CHI}$ patients in China.

\section{Acknowledgement}

We are grateful to Haitao Zhu and Zhe Yan of BGI Shenzhen in China for the exon sequencing of the genes. We also thank Ke Huang, Chunlin Wang, and the colleges from Children's Hospital, Zhejiang University, School of Medicine, for their assistance in providing us with the material for all exon sequencing. 


\section{Ethics}

Ethics Committee Approval: No ethics approval was required.

Informed Consent: No informed consent was required.

Peer-review: Externally peer-reviewed.

\section{Authorship Contributions}

Concept: Hui-Min Yu, Design: Tian-Ming Yuan, Data Collection and Processing: Wen-Ting Zhao, Analysis and Interpretation: Tai Wu, Literature Research: Yi Sun, Liang Wang, Writing: Wei-Yan Wang.

Financial Disclosure: The work of the authors is supported by Zhejiang Provincial Program for the Cultivation of Highlevel Innovative Health Talents and The National Natural Science foundation of China (81571466).

\section{References}

1. Mohamed Z, Arya VB, Hussain K. Hyperinsulinaemic hypoglycaemia: genetic mechanisms, diagnosis and management. J Clin Res Pediatr Endocrinol 2012;4:169-181. Epub 2012 Oct 2

2. Glaser B, Thornton P, Otonkoski T, Junien C. Genetics of neonatal hyperinsulinism. Arch Dis Child Fetal Neonatal Ed 2000;82:79-86.

3. Al-Nassar S, Sakati N, Al-Ashwal A, Bin-Abbas B. Persistent hyperinsulinaemic hypoglycaemia of infancy in 43 children: long-term clinical and surgical follow-up. Asian J Surg 2006;29:207-211.

4. Rahier J, Guiot Y, Sempoux C. Morphologic analysis of focal and diffuse forms of congenital hyperinsulinism. Semin Pediatr Surg 2011;20:3-12.

5. Saint-Martin C, Arnoux JB, de Lonlay P, Bellanne-Chantelot C. KATP channel mutations in congenital hyperinsulinism. Semin Pediatr Surg 2011;20:18-22

6. Snider KE, Becker S, Boyajian L, Shyng SL, MacMullen C, Hughes N, Ganapathy K, Bhatti T, Stanley CA, Ganguly A. Genotype and phenotype correlations in 417 children with congenital hyperinsulinism. J Clin Endocrinol Metab 2013;98:355-363. Epub 2012 Dec 28

7. Pinney SE, Ganapathy K, Bradfield J, Stokes D, Sasson A, Mackiewicz K, Boodhansingh K, Hughes N, Becker S, Givler S, Macmullen C, Monos D, Ganguly A, Hakonarson H, Stanley CA. Dominant form of congenital hyperinsulinism maps to HK1 region on 10q. Horm Res Paediatr 2013;80:18-27. Epub 2013 Jul 13

8. Tegtmeyer LC, Rust S, van Scherpenzeel M, Ng BG, Losfeld ME, Timal S, Raymond K, He P, Ichikawa M, Veltman J, Huijben K, Shin YS, Sharma V, Adamowicz M, Lammens M, Reunert J, Witten A, Schrapers E, Matthijs G, Jaeken J, Rymen D, Stojkovic T, Laforêt P, Petit F, Aumaître O, Czarnowska E, Piraud M, Podskarbi T, Stanley CA, Matalon R, Burda P, Seyyedi S, Debus V, Socha P, Sykut-Cegielska J, van Spronsen F, de Meirleir L, Vajro P, DeClue T, Ficicioglu C, Wada Y, Wevers RA, Vanderschaeghe D, Callewaert N, Fingerhut R, van Schaftingen E, Freeze HH, Morava E, Lefeber DJ, Marquardt T. Multiple phenotypes in phosphoglucomutase 1 deficiency. N Engl J Med 2014;370:533-542.

9. Fournet JC, Junien C. Genetics of congenital hyperinsulinism. Endocr Pathol 2004;15:233-240.

10. Su C, Gong C, Sanger P, Li W, Wu D, Gu Y, Cao B. Long-term follow-up and mutation analysis of 27 chinese cases of congenital hyperinsulinism. Horm Res Paediatr 2014;81:169-176. Epub 2014 Jan 9
11. Gong C, Huang S, Su C, Qi Z, Liu F, Wu D, Cao B, Gu Y, Li W, Liang X, Liu M. Congenital hyperinsulinism in Chinese patients: 5-yr treatment outcome of 95 clinical cases with genetic analysis of 55 cases. Pediatr Diabetes 2016;17:227-234. Epub 2015 Feb 2

12. Sang Y, Xu Z, Liu M, Yan J, Wu Y, Zhu C, Ni G. Mutational analysis of ABCC8, KCNJ11, GLUD1, HNF4A and GCK genes in 30 Chinese patients with congenital hyperinsulinism. Endocr J 2014;61:901-910. Epub 2014 Jul 8

13. Fan ZC, Ni JW, Yang L, Hu LY, Ma SM, Mei M, Sun BJ, Wang HJ, Zhou WH. Uncovering the molecular pathogenesis of congenital hyperinsulinism by panel gene sequencing in 32 Chinese patients. Mol Genet Genomic Med 2015;3:526-536

14. Rozenkova K, Guemes M, Shah P, Hussain K. The Diagnosis and Management of Hyperinsulinaemic Hypoglycaemia. J Clin Res Pediatr Endocrinol 2015;7:86-97.

15. Zhang $\mathrm{X}$, Tong $\mathrm{X}$, Zhang $\mathrm{B}$. Two case reports of neonatal hyperinsulinism[in Chinese]. Chin J Perinat Med 2002;5:45.

16. Wang $\mathrm{H}$, Lu $\mathrm{Q}$, Shi T, Zhou B. Three case reports of congenital hyperinsulinismin Chinese. CJCHC 2003;11:360.

17. Yu M, Chen D, Du M, Li Y, Li X. Early diagnosis and treatment of congenital hyperinsulinism:clinical analysis of 5 cases [in Chinese]. Chin J Prac Pediatr 2003; 18:421-423.

18. Yang B, Wen T, Dai X. Neonatal hyperinsulinism:one case report[in Chinese]. Chin J Pediatr 2004;42:332.

19. Yue S, Wang M, Wang Q, Yu X, Yang Y. Congenital hyperinsulinism: a difficult and complicated case study [in Chinese]. Chin J Contemp Pediatr 2006;8:391-394.

20. Su C, Gong C. Clinical analysis of 15 cases of neonatal congenital hyperinsulinism hypoglycemia [in Chinese] Chinese Jonrna1 of Practical Pediatrics Dec 2010;25:940-942.

21. San Y, Liu M, Yan J, Ni G. Treatment of congenital hyperinsulinism with diazoxide:seven case reports [in Chinese]. J Appl Clin Pediatr $2011 ; 26: 619-621$.

22. Shen L, Liu L, Li X, Shen H. Clinic and gene mutation analysis on 9 cases of persistant hyperinsulinemic hypoglycemia of infanty[in Chinese]. Guangdong Medical Journal 2012;33:1395-1399.

23. Sun B, Wang H, Liu M, Qin H, Li W, San Y, Zhu X, Zhu C. Therapeutic Effect of Subtotal Pancreatectomy On Three Patients with Congenital Hyperinsulinism[in Chinese]. J Appl Clin Pediatr 2012;27:1610-1612.

24. Hu S, Liu M, San Y. Treatment of congenital hyperinsulinism with octreotide: one case report [in Chinese]. Chin J Contemp Pediatr 2013;15:392-393

25. Xu Z, Liu M, Yan J, Xu Q, San Y. Gene mutation of glucokinase in one case of congenital hyperinsulinism[in Chinese]. Chin J Diabetes Mellitus 2016;8:237-240.

26. Yang L, Yang X, Shi J, Xiong Y. Neonatal congenital hyperinsulinism: one case report and literature review[in Chinese]. J Clin Pediatr 2016;34:188-191

27. Lee CT, Liu SY, Tung YC, Chiu PC, Wu MZ, Tsai WY. Clinical characteristics and long-term outcome of Taiwanese children with congenital hyperinsulinism. J Formos Med Assoc 2016;115:306-310. Epub 2015 May 7

28. Meissner T, Wendel U, Burgard P, Schaetzle S, Mayatepek E. Longterm follow-up of 114 patients with congenital hyperinsulinism. Eur J Endocrinol 2003;149:43-51.

29. Ferry RJ Jr, Kelly A, Grimberg A, Koo-McCoy S, Shapiro MJ, Fellows KE, Glaser B, Aguilar-Bryan L, Stafford DE, Stanley CA. Calciumstimulated insulin secretion in diffuse and focal forms of congenital hyperinsulinism. J Pediatr 2000;137:239-246. 
30. de Lonlay P, Fournet JC, Touati G, Groos MS, Martin D, Sevin C, Delagne V, Mayaud C, Chigot V, Sempoux C, Brusset MC, Laborde K, BellaneChantelot C, Vassault A, Rahier J, Junien C, Brunelle F, Nihoul-Fékété C, Saudubray JM, Robert JJ. Heterogeneity of persistent hyperinsulinaemic hypoglycaemia. A series of 175 cases. Eur J Pediatr 2002:161:37-48.

31. Demirbilek H, Shah P, Arya VB, Hinchey L, Flanagan SE, Ellard S, Hussain K. Long-term follow-up of children with congenital hyperinsulinism on octreotide therapy. J Clin Endocrinol Metab 2014:99:3660-3667. Epub 2014 Jun 17

32. Levy-Khademi F, Irina S, Avnon-Ziv C, Levmore-Tamir M, Leder O. Octreotide-associated cholestasis and hepatitis in an infant with congenital hyperinsulinism. J Pediatr Endocrinol Metab 2015:28:449-451.

33. Park SE, Flanagan SE, Hussain K, Ellard S, Shin $\mathrm{CH}$, Yang SW. Characterization of $\mathrm{ABCC} 8$ and $\mathrm{KCNJ} 11$ gene mutations and phenotypes in Korean patients with congenital hyperinsulinism. Eur J Endocrinol 2011;164:919-926. Epub 2011 Mar 21

34. Yorifuji T, Kawakita R, Nagai S, Sugimine A, Doi H, Nomura A, Masue
M, Nishibori H, Yoshizawa A, Okamoto S, Doi R, Uemoto S, Nagasaka H. Molecular and clinical analysis of Japanese patients with persistent congenital hyperinsulinism: predominance of paternally inherited monoallelic mutations in the KATP channel genes. J Clin Endocrinol Metab 2011;96:141-145. Epub 2010 Oct 13

35. Kapoor RR, Flanagan SE, Arya VB, Shield JP, Ellard S, Hussain K. Clinical and molecular characterisation of 300 patients with congenital hyperinsulinism. Eur J Endocrinol 2013;168;557-564.

36. Christesen HB, Tribble ND, Molven A, Siddiqui J, Sandal T, Brusgaard K, Ellard S, Njolstad PR, Alm J, Brock Jacobsen B, Hussain K, Gloyn AL. Activating glucokinase (GCK) mutations as a cause of medically responsive congenital hyperinsulinism: prevalence in children and characterisation of a novel GCK mutation. Eur J Endocrinol 2008:159:27-34. Epub 2008 May 1

37. Kapoor RR, Heslegrave A, Hussain K. Congenital hyperinsulinism due to mutations in HNF4A and HADH. Rev Endocr Metab Disord 2010:11:185-191. 